\title{
Mass Seed Production of Macrobrachium Idae (Heller, 1862)
}

\section{S Sudhakar, P Soundarapandian, D Varadharajan* and GK Dinakaran}

Faculty of Marine Sciences, Centre of Advanced Study in Marine Biology, Annamalai University, Parangipettai-608 502, Tamil Nadu, India

\begin{abstract}
In the present study, the mass larval culture experiments were carried out from naturally collected berried females and also unilateral eyestalk ablated females. The fecundity was more in the naturally collected berried females. It was ranged between 6,270 to $22,420.60$. Comparatively the fecundity was little bit low in the eyestalk ablated females. It was ranged between $6,186.66$ to $22,140.31$. The hatching rate was maximum in the naturally collected berried females $(96.89 \%)$. It was less $(93.21 \%)$ in the eyestalk ablated females. The incubation period for naturally collected females was 14.04 days and it was 14.86 days in eyestalk ablated females. The larval cycle was completed within 41.02 days in naturally collected berried female. Whereas it was 42.22 days in eyestalk ablated females. The survival rate of hatchlings was higher in naturally collected brooder $(73.34 \%)$ and it was less $(69.67 \%)$ in the eyestalk ablated females. In general survival rate of seeds is more than $70 \%$. The seed production technology followed in the present study is very simple and highly suitable for small scale farmers. So it is suggested that $M$. idae will be a one of the alternative species for the bigger sized prawns ( $M$. rosenbergii and $M$. malcomsonii) in freshwater aquaculture to meet the demand of high nutritional food in a cost effective manner.
\end{abstract}

Keywords: $M$. rosenbergii; Fecundity, Mass Seed; Low Cost Technology; Culture aspects

\section{Introduction}

The mass seed production technology is already well established for commercially important bigger sized prawns like $M$. rosenbergii and M. malcolmsonii. Around 300 commercial hatcheries are available for both east and west coast of India for the giant prawn,

$M$. rosenbergii and some extend in monsoon river prawn, $M$. malcolmsonii [1-3]. Several other species belongs to the genus Macrobrachium are highly suitable for culture in India even though they are smaller in size [1,3-5]. In general there is a substitute for everything and prawns are no exception. So $M$. idae are considered to be an alternative species for $M$. rosenbergii and M. malcolmsonii. Since there is no considerable information about the mass seed production of small prawns in general and $M$. idae in particular. So in the present study an attempt has been made to bring out the seed production technology for edible prawn, $M$. idae to popularize this species for aquaculture.

\section{Materials and Methods}

The animals were collected from Ponnanthittu (Lat. $11^{\circ} 28^{\prime} 41^{\prime \prime} \mathrm{N}$; Long. $79^{\circ} 45^{\prime} 30^{\prime \prime} \mathrm{E}$ ) waters which is located $2 \mathrm{~km}$ south to Parangipettai and connected with Vellar estuary. The prawns were caught by the fisherman with the help of trap, line and hand-net and scoop net. The specimens collected from the fisherman were ranged from 30 to 110 $\mathrm{mm}$ in length. Totally 150 specimens were collected and transported to the laboratory in live condition by keeping them in bucket containing freshwater and aeration. After reaching the laboratory they were washed carefully with distilled water to remove the dust and algal particles. The collected berried females were brought to the laboratory and immediately immersed in a prophylactic dip of $20 \mathrm{ppm}$ formalin for 30 minutes $[6,7]$. They were placed in brackish water with the salinity of $4-5 \mathrm{ppt}$ in fiberglass tank $(45 \times 30 \times 37 \mathrm{~cm})$. The water quality parameters were maintained as shown in Table 1 . They were fed with oyster meat and also commercially available pelleted feed twice a day. Left out feed was removed half an hour after it was offered so as to avoid spoilage of rearing water. Every day half of the water was replaced. Once the egg mass became dark grey on the larvae hatched out immediately at early morning. The hatched larvae were dispersed by the mother by the fanning movements of its pleopods. As soon as the hatching was completed the female was removed from the fiberglass tank and placed in another aquarium to avoid any predation by the mother itself.

\section{Larval management}

The larvae immediately after hatching was stocked at a density of 100 larvae/L in a $50 \mathrm{~L}$ fiberglass tanks. They were siphoned out very carefully so as to avoid the physical damage to the larvae. The optimum environmental parameters were maintained throughout the experiment. The water quality parameters followed are given in the Table 2 .

\section{Brackish water preparation and treatment}

Brackish water was prepared by mixing filtered seawater and freshwater and 12-14 ppt salinity was prepared. Sodium hypochloride solution $(\mathrm{NaOCl})$ was added to the prepared 12-14 ppt water, which was then aerated for $24 \mathrm{hrs}$. Excess chlorine was removed by treating

\begin{tabular}{|l|l|}
\hline Water quality parameters & Optimum range \\
\hline Temperature & $28-30^{\circ} \mathrm{C}$ \\
\hline Salinity & $4-5 \mathrm{ppt}$ \\
\hline Dissolved oxygen & 5.0 to $6.0 \mathrm{ppm}$ \\
\hline $\mathrm{pH}$ & 7.0 to 8.5 \\
\hline Photoperiod & $12 / 12 \mathrm{hL} / \mathrm{D}$ \\
\hline
\end{tabular}

Table 1: Water quality parameters of the brooders.

*Corresponding author: P. Soundarapandian, Faculty of Marine Sciences Centre of Advanced Study in Marine Biology, Annamalai University, Parangipettai-608 502, Tamil Nadu, India, Tel: 04144-243223; Fax: 04144-243553; E-mail: soundsuma@gmail.com

Received November 13, 2013; Accepted December 09, 2013; Published December 12, 2013

Citation: Sudhakar S, Soundarapandian P, Varadharajan D, Dinakaran GK (2013) Mass Seed Production of Macrobrachium Idae (Heller, 1862). J Aquac Res Development 5: 210 doi:10.4172/2155-9546.1000210

Copyright: (c) 2013 Sudhakar S, et al. This is an open-access article distributed under the terms of the Creative Commons Attribution License, which permits unrestricted use, distribution, and reproduction in any medium, provided the original author and source are credited. 


\begin{tabular}{|l|l|}
\hline Water quality parameters & Optimum range \\
\hline Temperature & $28 \pm 2^{\circ} \mathrm{C}$ \\
\hline Salinity & 12 to $14 \mathrm{ppt}$ \\
\hline Dissolved oxygen & 5.0 to $6.0 \mathrm{ppm}$ \\
\hline $\mathrm{pH}$ & 7.0 to 8.5 \\
\hline Photoperiod & $12 / 12 \mathrm{~h} \mathrm{~L} / \mathrm{D}$ \\
\hline
\end{tabular}

Table 2: Water quality parameters of the rearing larvae.

\begin{tabular}{|l|c|c|c|}
\hline Component & Quality (\%) & Nutrient content & $\%$ \\
\hline Shrimp meal & 15.0 & Protein & 35.0 \\
Oyster meat & 15.0 & Carbohydrate & 19.0 \\
Hens egg & 5.0 & Fat & 9.4 \\
Cooked and mashed rice & 8.0 & Ash & 7.3 \\
Milk powder & 4.5 & Moisture & 10.6 \\
Aminovit & 1.0 & & \\
Minerals & 1.5 & & \\
Water & 50.0 & & \\
\hline
\end{tabular}

Table 3: Composition and nutritive value of the artificial feed.

\begin{tabular}{|l|c|c|c|c|}
\hline Zoeal stages & $\begin{array}{c}\text { Quantity of } \\
\text { Artemia nauplii } \\
\text { per ml }\end{array}$ & $\begin{array}{c}\text { Size of } \\
\text { Artemia } \\
\text { nauplii }(\mathbf{m m})\end{array}$ & $\begin{array}{c}\text { Quantity of } \\
\text { artificial feed } \\
\mathbf{( g )}\end{array}$ & $\begin{array}{c}\text { Size of feed } \\
\text { particles } \\
\mathbf{( \mu g )}\end{array}$ \\
\hline II to III & 5 & 0.3 & - & - \\
\hline IV to V & 5 & 0.3 & 0.65 to 1.0 & 150 to 300 \\
\hline VI to VII & 8 & 0.3 & 2.00 to 3.0 & 300 to 400 \\
\hline VIII to X & 10 & 0.3 & 4.00 to 5.00 & 400 to 500 \\
\hline Post larvae & 10 & 0.3 to 1.0 & 6.00 to 8.00 & 600 to 800 \\
\hline
\end{tabular}

Table 4: Feeding schedule of both Artemia nauplii and artificial feed to the zoea stage to post larvae.

the water with sodium thiosulphate [8].

\section{Water exchange}

At every morning detritus and dead larvae were removed by turning off the aeration and siphoning the settled particles from the tank bottoms. Fifty percent of the water was exchanged each day. Aeration was provided continuously through an air diffuser.

\section{Live feed culture}

The Artemia nauplii were harvested from the Artemia hatching jar and placed in a plastic tub with required quantity of water. The enrichment solution (Culture Selco- INVE, Belgium) was added at a concentration of $0.1 \%$. The nauplii were enriched for 12 hours and after washing in seawater the nauplii were fed to the zoeal stages.

\section{Artificial feed}

Artificial feed was prepared in the combinations of hen's egg, shrimp meal, cooked and smashed rice, milk powder, aminovit and minerals. The ingredients were dried and powdered separately. The pellets were prepared by mixing together; the required quantities of the finally powered materials and the mixture were kneaded well by adding minimum quantity of water to form dough. The dough was cooked in a pressure cooker for 30 minutes and the cooked material was extruded through a hand pelletizer with required perforation in the form of noodles on a filter paper and oven dried at $60^{\circ} \mathrm{C}$. The dried pellets were broken into pieces of required length and stored in polythene bags for future use [9]. The proximate composition of the artificial feed was analyzed. The protein, carbohydrate and lipid contents were estimated by adopting the standard methods of [10-12] respectively. Ash and moisture was estimated by following the standard methods. The artificial feed composition and nutritive value are given in the Table 3.

\section{Feeding}

Even though newly hatched larvae could survive upto 5 days without food, they were provided with appropriate food from the second day onwards. Artemia nauplii were fed three times a day $(6.00$ am, 12 noon and $6.00 \mathrm{pm}$ ) from II zoeae to III zoeae at a rate of 5 nauplii/ $/ \mathrm{ml}$. Beginning from IV zoeae prepared feed was fed two times during the day time (6.00 am and 12 noon) and Artemia nauplii were fed only once in night $(7.00 \mathrm{pm})$ (Table 4$)$.

The amount of feed not consumed was carefully noted every morning and according to that the amount of next feeding was adjusted. The Artemia which were left out without consuming by the zoea were carefully removed next day before providing the fresh feed since Artemia has the ability to grow faster than the zoea and sometimes it may consume the zoea.

\section{Growth and developmental stages}

Growth and developmental stages including hatching status of the larvae were observed under binocular microscope. Identification of larval stages and size range is presented in the Table 5.

\section{Experiment II: Rearing of larvae by induced breeding technique}

The induced breeding technique is well established for marine shrimps. Whereas very few work was done so far in freshwater prawns $[7,13]$. There is no such work in $M$. idae till date. So in the present study induced breeding technique (Eyestalk ablation) was tried to know the effect of eyestalk ablation on maturation, spawning, hatching and survival percentage of the zoeal stages in M. idae.

\section{Selection of healthy brooder}

Matured and healthy brooders were collected as earlier for induced breeding technique. They were acclimatized to the laboratory conditions in the fiber glass tank (45 X 30 X $37 \mathrm{~cm})$. After acclimatization (temperature $28 \pm 2^{\circ} \mathrm{C}$, salinity $5 \mathrm{ppt}$, photophase $12 \mathrm{D}$ : $12 \mathrm{~L})$ the matured females were selected for eyestalk ablation.

\section{Method of eyestalk ablation}

In the present study unilateral eyestalk ablation was performed by severing the left eyestalk from the body at the narrow proximal end, in the region of the articulating membrane, using a pair of fine sterilized scissors [14]. The wound was cauterized by placing a hot blunt needle over it in order to prevent the loss of hemolymph and mortality.

\begin{tabular}{|c|c|c|}
\hline Zoeal stages & Prominent characters & Size range $(\mathrm{mm})$ \\
\hline I & Sessile eyes & $1.89-2.07$ \\
\hline II & Stalked eyes & 2.13-2.36 \\
\hline III & $\begin{array}{l}\text { Rostrum with epigastric tooth, uropod } \\
\text { developed }\end{array}$ & $2.37-2.52$ \\
\hline IV & Rostrum with 2 dorsal teeth & $2.53-2.62$ \\
\hline V & Buds of 4th pereiopod developed & 2.69-2.89 \\
\hline VI & All pereiopods developed & 3.02-3.97 \\
\hline VII & Uniramous buds of pleopods developed & $3.78-4.32$ \\
\hline VIII & Pleopods biramous & $4.34-5.03$ \\
\hline IX & $1^{\text {st }}$ and $2^{\text {nd }}$ pereiopods chelate & $5.04-5.76$ \\
\hline $\mathbf{x}$ & Appendix interna developed & $5.77-6.02$ \\
\hline Post-larvae & $\begin{array}{l}\text { Spines on ventral side of the rostrum } \\
\text { developed }\end{array}$ & $6.04-6.30$ \\
\hline
\end{tabular}

Table 5: Identification of larval stages. 
Citation: Sudhakar S, Soundarapandian P, Varadharajan D, Dinakaran GK (2013) Mass Seed Production of Macrobrachium Idae (Heller, 1862). J Aquac Res Development 5: 210 doi:10.4172/2155-9546.1000210

Page 3 of 5

\section{Maturation tanks}

The female was placed in a maturation tank immediately after eyestalk ablation. Optimum conditions were maintained in the maturation tank. The female was observed very carefully for its premating-moult. The female was once ready for pre-mating moult the matured male was introduced into the tank. Immediately after introduction of the male the female undergone pre mating moult, this attracted the male for mating. Since the female was very soft the male protect the female and was waiting for few hours until the female exoskeleton became slightly hard.

\section{Mating, spawning and hatching}

Immediately after mating, the females were laid their eggs within $24 \mathrm{hrs}$. The spawned females were transferred to the hatching tank and were maintained until the fertilized eggs were hatched into 1st zoeae. The total number of eggs, percentage of hatching and survival percentage were calculated for each berried female. Larval management and feeding were just like previous experiment. Triplicate was maintained for each experiment.

\section{Fecundity}

Immediately after extrusion of eggs to the brood chamber the eggs were manually removed from the abdomen of each female and egg clutch. The female weight was also determined separately. Egg clutch was weighed to the nearest $0.01 \mathrm{mg}$ after excess water had been removed by repeated blotting. The independent sample from the clutch was counted under a microscope to estimate the total number of eggs. Fecundity was estimated as the number of eggs per female weight (eggs/g of female), as well as the percentage of effort devoted to reproduction per spawning event (egg clutch weight/female weight $\times 100$ ).

\section{Statistical analysis}

To know the statistical significance, ' $t$ ' test was applied for the survival of zoea to post- larval stages of naturally collected berried and eyestalk ablated females. It showed significant difference $(\mathrm{P}<0.05)$.

\section{Results}

\section{Fecundity rate}

The fecundity of both females is displayed in the Table 6. Fecundity was more in the naturally collected berried females. It was ranged between 6,270 to $22,420.60$. It was little bit low in the eyestalk ablated females and ranged between $6,186.66$ to $22,140.31$.

\section{Hatching rate}

The hatching rate was maximum in the naturally collected berried females (96.89\%). It was less (93.21\%) in the eyestalk ablated females. Hatching of the eggs were observed in batches for both the experiments (Table 6).

\section{Incubation period}

The incubation period of the naturally collected females was about 14.04 days. Whereas it was 14.86 days in eyestalk ablated females (Table 6).

\section{Rearing periods}

The larval cycle was completed within $41.02 \pm 0.58$ days in naturally collected berried female. Whereas it was $42.22 \pm 0.38$ days in eyestalk ablated female to complete their larval cycle (Table 6).

\begin{tabular}{|l|l|l|}
\hline Particulars & $\begin{array}{l}\text { Naturally collected } \\
\text { berried females }\end{array}$ & $\begin{array}{l}\text { Eye stalk ablated } \\
\text { females }\end{array}$ \\
\hline Fecundity rate $\mathbf{( 7 0 - 9 0} \mathbf{~ m m})$ & $6,270 \pm 17.34-$ & $6,186.66 \pm 25.16-$ \\
& $22,420.60 \pm 31.11$ & $22,140.31 \pm 34.42$ \\
\hline Hatching rate (\%) & $96.89 \pm 0.55$ & $93.21 \pm 0.72$ \\
\hline Incubation period (\%) & $14.04 \pm 0.07$ & $14.86 \pm 0.21$ \\
\hline Rearing periods (\%) & $41.02 \pm 0.58$ & $42.22 \pm 0.38$ \\
\hline
\end{tabular}

Table 6: Fecundity, hatching rate, incubation period, rearing periods and survival rate of $M$. idae larvae reared in both naturally collected and eyestalk ablated females.

\begin{tabular}{|l|c|c|c|c|}
\hline & \multicolumn{2}{|c|}{ Naturally collected } & \multicolumn{2}{c|}{ Eyestalk ablated } \\
\hline Stage & $\begin{array}{c}\text { Number of } \\
\text { days after } \\
\text { hatching }\end{array}$ & Survival (\%) & $\begin{array}{c}\text { Number of } \\
\text { days after } \\
\text { hatching }\end{array}$ & Survival (\%) \\
\hline Zoea I & 0 & $97.66 \pm 0.57$ & 0 & $96.33 \pm 0.57$ \\
\hline Zoea II & $2.00 \pm 0.06$ & $96.33 \pm 1.52$ & $2.00 \pm 0.22$ & $95.66 \pm 2.08$ \\
\hline Zoea III & $5.52 \pm 0.05$ & $94.00 \pm 2$ & $5.12 \pm 0.26$ & $93.00 \pm 2.64$ \\
\hline Zoea IV & $7.84 \pm 0.12$ & $91.00 \pm 1.73$ & $8.00 \pm 0.36$ & $87.66 \pm 3.21$ \\
\hline Zoea V & $10.88 \pm 0.35$ & $88.00 \pm 3.60$ & $11.09 \pm 0.66$ & $86.00 \pm 5.51$ \\
\hline Zoea VI & $14.62 \pm 0.12$ & $84.00 \pm 3.60$ & $15.02 \pm 0.80$ & $81.33 \pm 5.03$ \\
\hline Zoea VII & $19.04 \pm 0.19$ & $82.00 \pm 4$ & $20.32 \pm 0.86$ & $77.66 \pm 3.05$ \\
\hline Zoea VIII & $24.42 \pm 0.11$ & $79.00 \pm 4.58$ & $25.30 \pm 1.13$ & $77.00 \pm 4.58$ \\
\hline Zoea IX & $31.22 \pm 0.20$ & $77.33 \pm 3.05$ & $32.03 \pm 1.16$ & $74.66 \pm 4.50$ \\
\hline Zoea X & $35.04 \pm 0.14$ & $77.00 \pm 3$ & $36.66 \pm 1.09$ & $72.33 \pm 1.52$ \\
\hline Post-larval & $41.02 \pm 0.58$ & $73.34 \pm 2.51$ & $42.22 \pm 0.38$ & $69.67 \pm 5.50$ \\
\hline
\end{tabular}

Table 7: Larval development, moulting period and survival (\%) of naturally collected and eyestalk ablated berried females of $\mathrm{M}$. idae (values are mean of three values \pm SE).

\begin{tabular}{|c|c|c|}
\hline Survival rate & Degrees of freedom & 't' value \\
\hline I & 2 & 4 \\
\hline II & 2 & 1 \\
\hline III & 2 & 0.58 \\
\hline IV & 2 & 3.77 \\
\hline VI & 2 & 0.38 \\
\hline VII & 2 & 0.54 \\
\hline VIII & 2 & 1.3 \\
\hline IX & 2 & 0.38 \\
\hline X & 2 & 0.61 \\
\hline Post-larva & 2 & 1.79 \\
\hline
\end{tabular}

Significantly different $(P<0.05)$

Table 8: Results of 't' test for the survival of zoea to post- larval stages of naturally collected and eyestalk ablated berried females.

\section{Survival rate}

The survival rate of hatchlings was higher in naturally collected brooder (73.34\%). And it was less (69.67\%) in the eyestalk ablated females (Table 7). The survival showed significant variation between naturally collected and eyestalk ablated females (Table 8).

\section{Discussion}

In decapod crustaceans, regulation of all organ systems depends on the integration of nervous and endocrine systems. The neuroendocrine system controls physiological processes related to moulting, growth and sexual maturation [15]. The X-organ-sinus gland (XO-SG) complex located in the eyestalk is the major neuroendocrine control center of crustaceans [16]. In unilaterally eyestalk ablated prawn moulting frequency was more and the intermoult period in the subsequent moults become shorter when compared to intact control animals in M. malcolmsonii [17]. Mortality was high in bilaterally 
ablated prawns ( $M$. rosenbergii and M. malcolmsonii) and survived upto first moult. They were feeding well and active after operation, but after that they became pale, weak and died at various time intervals [13]. Studies on the possible effects of eyestalk removal on gonad development in crustaceans are suggested that eyestalk contains gonad inhibiting hormone which delays gonad development [14]. The gonad development is accelerated after eyestalk ablation by influencing Gonad Stimulating Hormone (GSH). [7] observed that pre-mating moult and gonad development was started after eyestalk ablation in M. idella idella. In the present study also immediately after eyestalk ablation pre-mating moult and gonad development was initiated and therefore vitellogenesis and spawning takes place in very short period.

Eggs hatching in batches were considered to be a common feature in Macrobrachium [17-20]. Ignatius and Thampy [21] observed that the occurrence of batch hatching is an index of unfavorable condition. According to [19], the zoea released from single batch was found to be uniformly healthy. [20] remarked that the batch hatching of larvae shows slow growth rate and uneven stages. [22,23] referred that last few batches were too weak to escape predation and to catch prey efficiently. [19] also observed cannibalism in batch hatching. Batch hatching was common for both eyestalk ablated and naturally collected females of the present study. The hatching rates in naturally collected berried females were $96.89 \%$ and in eyestalk ablated females it was about $93.21 \%$.

The adults of Macrobrachium spp are known to migrate to the brackish water for breeding purpose [9]. The presence of less saline water (4-6 ppt) provides a better medium for hatching of $M$. rosenbergii eggs [9,13], M. malcolmsonii [6,8] and M. idella idella [7]. Katre and Pandian [24] confirmed that the eggs of M. idae are able to "pick up" salts from brackish water more readily than from freshwater. In the present study for the experiment I, the berried females were mostly collected from the estuary where the salinity was above 5 ppt. It clearly shows that berried females migrate to suitable salinity area. In the second experiment also after mating the berried females were transferred to the tank had 5ppt salinity so that the embryos were developed healthy.

Variation of the nutritional values in live feeds is recognized and thus formulated diets have been introduced $[25,26]$. Successful culture of crustaceans depends on the surrounding environment, quality and types of feeds [27]. Recent improvement of the formulated diets has been shown to be as efficient as live Artemia in supporting growth and survival of the larvae of giant freshwater prawn, $M$. rosenbergii [28]. Crustacean larvae are aggressive feeders and feed primarily on live feeds, i.e., small zooplankton and larval stages of other aquatic invertebrates $[29,30]$. In the present study the rearing of the larvae are very successful because both live Artemia nauplii and formulated feeds are provided as earlier studies [7,8]. After metamorphosed into post larvae, they resemble miniature adults and gradually change from suspending in the water to dwelling at the bottom.

Artemia nauplii constitute the main live feed and are most efficient to date. However as use of Artemia increases, so does cost of production $[6,31]$. Therefore, from the second day of rearing, Artemia nauplii were fed three times a day and prepared feed was used as a substitute from eighth day at 6.00 am and 12 noon and Artemia nauplii only once in night $(7.00 \mathrm{pm})$. In the case of prepared feed, it is advisable to consider the following points, over feeding will pollute the culture water, and under feeding causes malnutrition and cannibalism. Cannibalism was observed when the larvae metamorphosed into post larvae. $[8,13]$ also reported cannibalism in their experiments when post larvae appeared. Feed quality and feeding technique would be an important factor for successful larval rearing. The exact quantity of the feed required at each meal cannot be prescribed [32], since it depends on the utilization of the feed by the larvae and must be judged visually by the operator. Larvae in "poor" conditions were sluggish, did not respond well to the feed, were not strong enough to swim against the air bubbles, accumulated at the bottom of the tank, were often bluish in colour and sometimes jumped out of water. Healthy larvae swam at the water surface, fed actively, had reddish brown pigmentation and were not observed to cannibalize each other. They swim tail first, head down and ventral side up.

The newly hatched larva of $M$. idae is a typical zoea having close resemblance to those of other species of the genus Macrobrachium, which have a long larval history. Although, the specific identifications of the larvae of this species as well as those of the same genus is a difficult task. The general pattern of larval development of $M$. idae has close similarities with that of $M$. rosenbergii [33-35]. M. carcinus [36] and $M$. malcolmsonii [31]. In the present study it has been observed that the zoea of $M$. idae undergoes 10 morphological stages have been recognized and described. [33] found 12 zoeal stages in M. rosenbergii but in a subsequent study [34] grouped these larvae into 8 morphological stages. [37] described 11 zoeal stages in the developmental of the same species from Japan. [38] described 16 stages in M. malcolmsoni. [39] found 10 morphological stages in the zoeal development of $M$. acanthurus and 12 stages in $M$. carcinus. [7] found 10 morphological stages in the zoeal development of $M$. idella idella. Ten morphological stages in the larval development of most of the species of Macrobrachium appear to be a common feature. Reduction in the total length of larvae during its metamorphosis from last zoea to post-larva is noticed in several species of Macrobrachium [38]. In M. idae reduction of length of post-larva was not noticed for both the experiments in the present investigation and 10 zoeal stages were observed.

The newly hatched larvae of $M$. idella idella became mature and spawn within 120 days in the laboratory [40]. In nature this species may spawn at still shorter intervals. Once maturity is attained the species continues to spawn every 20 days, each time producing as many as 5000 larvae. In present study $M$. idae matured and spawn within 120-122 days. These characteristic of the species together with its readiness to spawn in confined waters make it an ideal species for culture operations in brackish waters. Besides, it would appear that $M$. idae is a species which can be cultivated entirely in brackish water environments. [41] stated that approximately $8000 \mathrm{Km}$ of brackish water areas presently unutilized along the coastal regions of India can be brought under effective prawn cultivation by adopting modern culture techniques. Commercial culture of this species in this area will, no doubt, be very profitable and it will certainly add new dimensions to the development of prawn fishery in the country. In rearing $M$. rosenbergii, survival rates are dependent on several factors such as stocking densities [42], water volume/surface area [27], $\mathrm{pH}$ level of water [43] and food supplement [30]. The survival rate of PL is 73.34 \pm 0.09 for the larvae reared from naturally collected berried females. It was $69.67 \pm 0.21$ for the larva from eyestalk ablated females. In both the experiments common environmental parameters were maintained. But the survival rate was higher for naturally collected brooder rather than eyestalk ablated animal.

In the present study it is clear that the larva of both the experiment doesn't have much variation. Even though the larva hatched from the naturally collected berried females had some advantage. But we cannot get the berried females throughout the year since it is restricted to some seasons. So in that case if we are going for hatchery production is better to adopt induced breeding technique which able to supply larvae 
Citation: Sudhakar S, Soundarapandian P, Varadharajan D, Dinakaran GK (2013) Mass Seed Production of Macrobrachium Idae (Heller, 1862). J Aquac Res Development 5: 210 doi:10.4172/2155-9546.1000210

irrespective of the season and this technique is already well established for other commercially important shrimps and prawns. The hatchery technology followed in this experiment is quite simple and can be applied to small-scale operations.

\section{References}

1. Rao KJ (1998) Emerging Technology on the Seed Production of Macrobrachium rosenbergii. In: Thomas, P. C. (Ed.), Current and Emerging Trends in Aquaculture. Daya Publishing House, New Delhi.164-169.

2. Soundarapandian P, Ananthan G, Kannupandi T (2006) Mass Seed Production of Macrobrachium malcolmsonii ( $\mathrm{H}$. Milne Edwards) in Synthetic Brackish Water. Indian J Fish 53: 91-96.

3. Soundarapandian P, Prakash KS, Dinakaran GK (2009) Simple Technology for the Hatchery Seed Production of Giant Palaemonid Prawn Macrobrachium rosenbergii (De Man). Inter J Ani Veter Advan 1: 49-53.

4. Cavalli RO, Lavens P, Sorgeloos P (2001) Reproductive Performance of Macrobrachium rosenbergii Female in Captivity. J World Aquacult Soc 32: 60-67.

5. Nhan DT (2009) Optimization of Hatchery Protocols for Macrobrachium rosenbergii Culture in Vietnam. Ph.D Thesis, Ghent University, Belgium. 265.

6. Soundarapandian P, Kannupandi T (2000) Effect of Feed on Larvae of Macrobranchium malcolmsonii ( $\mathrm{H}$. Milne Edwards) Reared in Synthetic Brackish Water. Indian J Exp Biol 38:287-289.

7. Dinakaran GK (2010) Mating Behaviour, Embryonic Development, Biochemica Composition and Mass Seed Production of Edible Prawn Macrobrachium idella idella (Hilgendorf, 1898). Ph. D Thesis, Annamalai University. 1-178.

8. Soundarapandian P, John Samuel M, Kannupandi T (1997) A Simple Method For The Seed Production of Freshwater Prawn Macrobrachium malcolmsonii (H.Milne Edwards). J Aqua Trop 12: 261-266.

9. John Samuel M, Soundarapandian P, Kannupandi T (1997) In Vitro Embryo Culture and Effect of Salinity on the Embryonic Development of The Cultivable Freshwater Prawn Macrobrachium malcomsonii (H. Milne Edwards). Cur Sci 73: 294-297.

10. Raymont JEG, Austin J, Linford E (1964) Biochemical Studies on Marine Zooplankton .I. The Biochemical Composition of Neomysis integer. J Cons Perm Explor Mar 28: 354-363.

11. Dubois M, Giles KA, Hamilton JK, Rebors PA, Smith F (1956) Calorimetric Method for Determination of Sugar and Related Substances. Analyt Chem 28: 350-356

12. Folch J, Lees M, Sloane-Stanley GH (1956) A Simple Method for the Isolation and Purification of Total Lipids from Animal Tissues. J Biol Chem 226: 497-509.

13. Soundarapandian P, John Samuel M, Kannupandi T (1995) Seasonal Variation in Production of Macrobranchium rosenbergii Postlarvae Reared at Ambient Temperatures in a Hatchery. World Aquacult 26: 38-40.

14. Caillouet CW Jr (1973) Ovarian Maturation Induced by Eyestalk Ablation in Pink Shrimp Penaeus duorarum Burkenroab. Proc.3rd Ann Workshop World Maricult Soc 3: 205-225.

15. Cooke IM, Sullivan RE (1982) Hormones and Neurosecretion. In: Atwood, HL Sandeman, DC (Eds.) Academic Press NY Biol Crust 3: 205-290.

16. De Kleijn DPN, Coenen T, Laverdure AA, Tensen CP, Van Harp F (1992) Localizaton of Messenger Rnas Encoding Crustacean Hyperglycemic Hormone and Gonad Inhibiting Hormone in the X-Organ Sinus Gland Complex of The Lobster Homarus americanus. Neurosci 51: 121-128.

17. Balasundaram C, Pandian TJ (1981) Invitro Culture of Macrobrachium Eggs. Hydrobiol 77: 203-207.

18. Mathavan S, Murugadass S (1988) An Improved Design for Invitro Hatching of Macrobrachium Eggs. Asian Fish Sci 1: 197-201.

19. Jayalakshmy B, Natarajan P (1996) Influence of Salinity on Fertilization and Hatching of Macrobrachium idella Under Laboratory Condition. J Aqua Trop 11:33-38.

20. Ranjeet K, Kurup BM (2000) Effect of Hatching Intensity on Growth and Metamorphosis of Larvae of Macrobrachium rosenbergii (De Man). Nat Workshop Aquacult Freshwater Prawns, College of Fishery Science, Nellore (AP), February 8-9: 26.
21. Ignatius CA, Thampy DM (1990) The Influence of Salinity on Reproduction in the Palaemonid Prawn, Macrobrachium idella (Hilgendorf). Second Indian Fishes Forum, Mangalore. 27-31: 100.a

22. Pandian TJ, Katre S (1972) Effect of Hatching Time on Larval Mortality and Survival of the Prawn Macrobrachium idae. Mar Biol 13:330-337.

23. Rajyalakshmi T (1960) Observations on the Embryonic and Larval Development of Some Estuarine Palaemonid Prawns. Proc Nat Inst Sci India 26 B: 395-408.

24. Katre S, Pandian TJ (1972) On Hatching Mechanism of Freshwater Prawn Macrobrachium idae. Hydrobiol 40: 1-17.

25. Jones DA, Kamarudin MS, Le Vay LL (1993) The Potential for the Replacement of Live Feeds in Larval Culture. J World Aquac Soc 24: 199-210.

26. Kumlu M, Jones DA (1995) The Effects of Live and Artificial Diets on Growth Survival, and Trypsin Activity in Larvae of Penaeus indicus. J World Aquac Soc 26: 406-415.

27. D'Abramo LR, Daniels WH, Gerard PD, Jun WH, Summerlin CG (2000) Influence of Water Volume, Surface Area, and Water Replacement Rate on Weight Gain of Juvenile Freshwater Prawns, Macrobrachium rosenbergii. Aquacult 182: 161-171.

28. Kovalenko EE, D'Abramo LR, Ohs CL, Buddington RK (2002) A Successful Microbound Diet for the Larval Culture of Freshwater Prawn Macrobrachium rosenbergii. Aquacult 210: 385-395.

29. Emmerson WD (1984) Predation and Energetics of Penaeus indicus (Decapoda, Panaeidae) Larval Feeding on Branchionus plicatilis and Artemia nauplii. Aquacult 38: 201-209.

30. Barros HP, Valenti WC (2003) Food Intake of Macrobrachium rosenbergii During Larval Development. Aquacult 216: 165-176.

31. Sorgeloos P (1976) The Brine Shrimp Artemia salina: A Bottleneck in Mariculture. FAO Tech Confer Aquacult, Kyoto, Japan. 5.

32. New MB, Singholka S (1985) Freshwater Prawn Farming- A Manual for the Culture of Macrobrachium rosenbergii. FAO Fish Tech Pap 225: 1-118.

33. Ling SW (1962) Studies on the Rearing of Larvae and Juveniles and Culturing of Adults of Macrobrachium rosenbergii (De Man). Indo-Pacif. Fish Coun Curr Affairs Bull 35: 1-11.

34. Ling SW (1969) Methods of Rearing and Culturing Macrobrachium rosenbergi (De Man). Ibid (57) 3: 607-619.

35. Uno Y, Sao KC (1969) Larval Development of Macrobrachium rosenbergii (De Man) Reared in The Laboratory. J Tokyo Univ Fish 55: 179-190.

36. Choudhury PC (1971) Laboratory Rearing of Larvae of the Palaemoni: Shrimp Macrobrachium acanthurus Wiegmann, 1836. Crusta 21: 113-125.

37. Kewalramani HG, Sankolli KN, Shenoy SS (197) On the Larval History of Macrobrachium malcolmsonii ( $\mathrm{H}$. Milne-Edward), In Captivity. J Indian Fish Assoc 1:1-25.

38. Uno Y, Kwon CS (1969) Larval Development of Macrobrachium rosenbergi Reared in the Laboratory. J Tokyo Univ Fish 55: 179-190.

39. Choudhury PC (1970) Complete Larval Development of Palaemonid Shrimp Macrobrachium acanthurus, Wiegmann, 1836. Reared in the Laboratory. Crusta 18:113-132

40. Pillai NN, Mohamed KH (1973) Larval History of Macrobrachium idella (Hilgendorf) Reared in the Laboratory. J Mar Biol Ass Indian 15: 359-385.

41. Mohamed KH (1972) Marine Prawn Culture in India-An Appraisal of the Present Status and Future Prospects. Proc. Seminar on Mariculture and Mechanized Fishing. Madras Dept Fish Govt. of Tamilnadu. 31-33.

42. Marques HLA, Lombardi JV, Boock MV (2000) Stocking Densities for Nursery Phase Culture of the Freshwater Prawn Macrobrachium rosenbergii In Cages. Aquacult 187: 127-132.

43. Chen SM, Chen JC (2003) Effects of pH on Survival, Growth, Molting and Feeding of Giant Freshwater Prawn Macrobrachium rosenbergii. Aquacult 218 613-623. 